(jasmani)

\title{
HUBUNGAN ANTARA POWER OTOT TUNGKAI, KEKUATAN OTOT LENGAN DAN KELENTUKAN DENGAN KEMAMPUAN LONCAT KATAK KIDS ATHLETIC PADA SISWA PUTRA KELAS 4 DAN 5 SD IT ABU JAFAR TAHUN AJARAN 2020/2021
}

\author{
Jasmani \\ Jasmani_utp@gmail.com \\ Universitas Tunas Pembangunan Surakarta
}

\begin{abstract}
ABSTRAK
Tujuan dari penelitian ini adalah untuk mengetahui: (1) Hubungan antara Power Otot Tungkai Dengan Kemampuan Loncat Katak Kids Athletic Pada Siswa Putra Kelas 4 Dan 5 SD IT Abu Jafar Tahun Ajaran 2020/2021. (2) Hubungan antaraKekuatan Otot Lengan Dengan Kemampuan Loncat Katak Kids Athletic Pada Siswa Putra Kelas 4 Dan 5 SD IT Abu Jafar Tahun Ajaran 2020/2021. (3) Hubungan antara KelentukanDengan Kemampuan Loncat Katak Kids Athletic Pada Siswa Putra Kelas 4 Dan 5 SD IT Abu Jafar Tahun Ajaran 2020/2021. (4) Hubungan antara, Power Otot Tungkai, Kekuatan Otot Lengan Dan Kelentukan Dengan Kemampuan Loncat Katak Kids Athletic Pada Siswa Putra Kelas 4 Dan 5 SD IT Abu Jafar Tahun Ajaran 2020/2021.

Sesuai dengan tujuan penelitian ini, maka penelitian ini menggunakan metode deskriptif dengan pendekatan studi korelasional.Penelitian ini dilaksanakan di Lapangan SD IT Abu Jafar Tahun Ajaran 2020/2021dan penelitian ini dilaksanakan pada bulan Oktober 2020.

Dalam penelitian ini variabel bebas disebut juga sebagai prediktor dan variabel terikat yang disebut juga sebagai kriterium. Teknik pengumpulan data dalam penelitian ini adalah menggunakan teknik tes dan pengukuran. Berdasarkan analisis data dan pengujian hipotesis yang telah dilakukan, maka simpulan yang dapat diperoleh adalah: (1) Ada hubungan yang signifikanantara Power Otot Tungkai dengan Lompat katak, $r_{\text {hitung }}=0,473>r_{\text {tabel } 5 \%}=0,361$. (2) Ada hubungan yang signifikan antara Kekuatan Otot Lengan dengan Lompat katak, $r_{\text {hitung }}=0,441>r_{\text {tabel }} \%=0,361$. (3) Ada hubungan yang signifikan antara Kelentukan dengan Lompat katak, $r_{\text {hitung }}=0.469>r_{\text {tabel }} \%=0,361$. (4) Ada hubungan yang signifikan antara Power Otot Tungkai, Kekuatan Otot Lengan dan Kelentukan dengan Lompat katak, $R_{y(123)}^{2}$ sebesar $0.407>r_{\text {tabel5 } \% \text { pada taraf }}$ signifikansi $5 \%$ sebesar 0.361 dan $F_{0}$ sebesar $7.5284>f_{\text {tabel }}$ pada taraf signifikansi $5 \%$ sebesar 2,89.
\end{abstract}

Kata Kunci: Power Otot Tungkai, Kekuatan Otot Lengan, Kelentukan Loncat Katak Kids Athletic 


\section{PENDAHULUAN}

Olahraga atletik merupakan salah satu mata pelajaran yang wajib diajarkan pada siswa di Sekolah Dasar (SD).Menurut Tisnowati Tamat (2003:2.3) atletik adalah salah satu cabang olahraga yang tertua yang dilakukan oleh manusia sejak jaman Yunani Kuno sampai dewasa ini. Dalam mata pelajaran atletik yang dipelajari adalah gerakan dasar manusia di dalam kehidupan seharihari, yaitu berjalan, berlari, melompat dan melempar.Selain itu dalam kejuaraan atletik ada beberapa nomor yang diperlombakan antaranya adalah nomor lari, jalan cepat, nomor lompat dan nomor lempar. Khusus untuk nomor lompat yang diperlombakan baik yang bersifat nasional maupun internasional terdiri dari nomor : lompat jauh, lompat tinggi, lompat jangkit dan lompat tinggi galah.

Berkaitan dengan pembinaan olahraga melalui pelaksanaan pendidikan jasmani di sekolah-sekolah, pola pembinaan usia dini yang dimasukkan dalam program Indonesia Bangkit (IB) merupakan program yang tidak bisa dipisahkan dari pembinaan olahraga melalui pendidikan jasmani. Ini disebabkan karena, secara umum anak usia dini merupakan anak yang sedang dalam masa sekolah baik SD, atau SMP. Namun demikian salah satu hal yang menjadi dasar dari keberhasilan dalam pembinaan usia dini adalah proses penyaringan anak usia sekolah sebagai calon bibit atlet (talent identification), untuk dibina sebagai bibit atlet dalam konteks pembinaan olahraga usia dini.

Power adalah kemampuan otot untuk menggerakkan kekuatan maksimal dalam waktu cepat.Dalam penelitian ini power otot tungkai adalah kemampuan otot tungkai untuk menggerakkan otot untuk mendapat hasil lompatan yang maksimal. Kekuatan otot lengan adalah kemampuan otot atau segerombol otot di lengan untuk mengatasi suatu beban atau tahanan untuk menjalankan suatu aktivitas.Kemampuan untuk melakukan passing bawah terhadap bola-bola tersebut dibutuhkan kekuatan otot lengan yang memadai, sehingga bola dapat dimainkan untuk selanjutnya dapat mendukung serangan. 
(jasmani)

Kelentukan atau fleksibilitas adalah kemampuan persendian beserta otot - otot di sekitarnya untuk melakukan gerak secara maksimal tanpa ada gangguan pada persendian tesebut.Faktor utama yang menentukan kelentukan seseorang adalah bentuk sendi elastisitas otot dari ligamen.Kelentukan merupakan salah satu komponen fisik yang sangat penting kaitannya dengan kemampuan loncat katakKids Athletic.Kelentukan diperlukan untuk membantu keberhasilan pelaksanaan loncat katakKids Athletic.Di samping itu, kelentukan berperan pula untuk mengurangi terjadinya cedera.

\section{LANDASAN TEORI}

\section{Perngertian KID's athetics}

Menurut Suyono (2002: 5) Kid's athletics adalah cabang olahraga atletik khusus untuk anak-anak yang di lakukan secara individu maupun kelompok dalam bentuk perlombaan sehingga melatih anak untuk berkompetisi dalam permainan yang menyenangkan. Peralatan yang digunakan dalam kid's athletics tidak sepertipada olahraga atletik dewasa namun disesuaikan karakteristik dan perkembangan anak, sehingga anak lebih mudah melakukan setiap gerakangerakan yang terdapat dalam gerak dasar atletik seperti gelang estafet, lembing anak (turbo), gawang, cones. Kid's Athletics merupakan cabang olahraga atletik yang dikhususkan untuk pendidikan jasmani anak Sekolah Dasar (SD). Jenis cabang olahraga ini diperkenalkan pertama kali oleh IAAF (International Association of Athletics Federation) kemudian disebarkan ke sekolah sekolah dasar melalui pendidikan dan pelatihan oleh Pusat Pembinaan Atletik Pelajar (PPAP). Sebagai ibu dari semua cabang olahraga sudah pada tempatnya atletik menjadi cabang olahraga wajib bagi pelajar sekolah dasar.

Menurut Suyono (2002: 5) Kid's Athletics yaitu program pembinaan atletik bagi atlet usia pelajar sekolah dasar sesuai dengan kebijakan IAAF. Nomornomor perlombaannya adalah sprint dan gawang (kanga's escape), loncat katak (frog jump), lempar turbo (turbo throwing) dan formula 1. Atletik anak - IAAF menyuguhkan/ memberikan kegembiraan; latihan-latihan event baru dan 
(jasmani)

gerakan-gerakan wajib yang beragam memerlukan penguasaan dalam lingkup suatu team/regu pada lokasi yang berbeda-beda di dalam lingkungan area lomba.Lebih lagi, event ini memungkinkan bagi suatu jumlah besar anak-anak untuk berpartisipasi di dalamnya dalam kemungkinan area yang terdekat dan di dalam suatu periode waktu yang dapat diperhitungkan.Dengan gerakan atletik dasar pada Atletik Anak - IAAF (lari, lari daya tahan, lompat, lempar) dapat dilakukan dan dilatihkan dalam suatu suasana bermain.Tuntutan phisiknya adalah mudah dan memungkinkan bagi tiap individu anak untuk siap-siaga berpartisipasi ikut serta. Atletik Anak -I AAF (Kid's' Athletics) event-eventnya memberikan kesempatan untuk mendemonstrasikan dan meng-ilhami daya tarik yang kuat/ pesona tentang atletik dalam setiap tempat umum/ publik, misalnya: pusat-pusat latihan.

\section{Loncat Katak Kid's' Athletics}

Suyono.(2002)Loncat katak merupakan salah satu jenis keterampilan melompat dengan kedua kaki ke depan sejauh mungkin. Tujuan loncat katak adalah untuk mencapai lompatan yang sejauh-jauhnya. Loncat katak merupakan salah satu nomor lompat dalam perlombaan kids athletic.

Nomor loncat katak Kids Athletic ini dilakukan dengan cara mengayun dengan tumpuan dua kaki dan mendarat dengan dua kaki pula. Dari garis start seorang melakukan "loncat katak" tiga kali berturut-turut. Cara penilaian diukurdari bagian tubuh yang terdekat dari garis start. Bila terjatuh ke belakang maka tandanya adalah pada tangan yang terdekat dengan garis start.

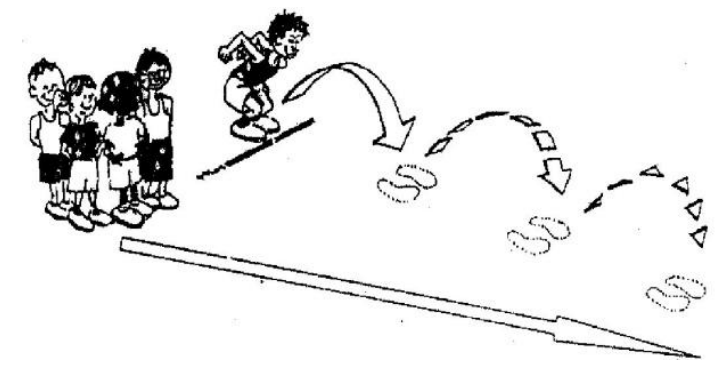

Gambar 1

Teknik Loncat katak Kids Athletic 
Dari uraian tersebut dapat dirumuskan bahwa, gerakan Loncat katak merupakan bentuk gerakan melompat, mengangkat kaki keatas dan kedepan dalam upaya membawa titik berat badan selama mungkin di udara yang dilakukan tolakan pada dua kaki untuk mencapai jarak yang sejauh-jauhnya. Dalam perlombaan Loncat katak, seorang pelompat akan berusaha melompat ke depan.

\section{Power Otot Tungkai}

Dengan memperhatikan pendapat di atas jelas bahwa daya ledak atau power merupakan kemampuan dari otot untuk mempergunakan kemampuan yang maksimal dalam waktu yang singkat. Apabila memperhatikan pendapat di atas, jelas tersirat bahwa power merupakan perpaduan antara kekuatan dan kecepatan, hal ini sesuai dengan pendapat dari M. Sajoto (1995 : 9) bahwa, "Daya otot = kekuatan (force)X kecepatan(Velocity)."

\section{A. Faktor-faktor yang Mempengaruhi Power}

Aktifitas power yang banyak dilakukan pada olah raga adalah gerakan power otot tungkai. Power otot tungkai dipengaruhi oleh kekuatan dan kecepatan otot.Kekuatan merupakan dasar untuk membentuk power. Menurut Suharno HP. (1993:59) factor-faktor penentu power adalah sebagai berikut :

1) Banyak sedikitnya macam fibril otot putih (phasic) dari atlet.

2) Kekuatan otot dan kecepatan otot.

3) Waktu rangsangan dibatasi secara konkrit lamanya.

4) Koordinasi gerakan yang harmonis.

5) Tergantung banyak sedikitnya zat kimia dalam otot (ATP).

6) Koordinasi gerakan yang harmonis.

\section{Kekuatan Otot Lengan}

Kekuatan otot merupakan komponen kondisi fisik yang mempunyai peran penting dalam melakukan aktivitas sehari-hari atau melakukan olahraga. Kekuatan sangat berperan penting dalam meningkatkan komponen kondisi fisik secara keseluruhan. Dengan kekuatan, maka dalam melakukan aktivitas sehari- 
(jasmani)

hari dapat dilakukan dengan baik dan prestasi olahraga dapat dicapai lebih optimal. Kekuatan merupakan kemampuan otot atau sekelompok otot yang dikerahkan secara maksimal untuk mengatasi suatu beban atau tahanan. Berkaitan dengan kekuatan, Dangsina Moeloek dan Arjatmo Tjokronegoro (1984 : 4) menyatakan, "kekuatan otot menggambarkan kontraksi maksimal yang dihasilkan oleh otot atau sekelompok otot". Menurut KONI (1993 : 17) bahwa, "kekuatan adalah kemampuan otot untuk membangkitkan tegangan terhadap suatu tahanan".Menurut Suharno HP. (1993 : 39) menyatakan bahwa, "Kekuatan adalah kemampuan otot untuk dapat mengatasi tahanan atau beban, menahan atau memindahkan beban dalam menjalankan aktivitas". Hal senada dikemukakan PBVSI (1995 : 40) bahwa, "kekuatan adalah kemampuan otot untuk dapat mengatasi tahanan atau beban, menahan atau memindahkan beban dalam menjalankan aktivitas olahraga".

Berdasarkan batasan kekuatan otot yang dikemukakan oleh empat ahli tersebut dapat disimpulkan bahwa, secara umum yang dimaksud dengan kekuatan otot adalah kemampuan otot atau segerombol otot untuk mengatasi suatu beban atau tahanan untuk menjalankan suatu aktivitas.Berdasarkan pengertian kekuatan otot tersebut dapat dirumuskan pengertian kekuatan otot lengan adalah kemampuan otot atau segerombol otot di lengan untuk mengatasi suatu beban atau tahanan untuk menjalankan suatu aktivitas.

\section{Kelentukan Togok}

Kelentukan penting sekali hampir ada pada semua cabang olahraga, terutama cabang - cabang olahraga yang banyak menuntut gerak sendi seperti senam, loncat indah, beberapa nomor atletik, pemainan - permainan dengan bola, dan lain sebagainya.Kelentukan juga penting bagi semua orang dari segala umur.Dengan kelentukan yang dimiliki memungkinkan gerakan yang dilakukan menjadi lebih baik.

Kelentukan atau fleksibilitas adalah kemampuan persendian beserta otot - otot di sekitarnya untuk melakukan gerak secara maksimal tanpa ada gangguan 
(jasmani)

pada persendian tesebut.Faktor utama yang menentukan kelentukan seseorang adalah bentuk sendi elastisitas otot dari ligamen. Bekaitan dengan kelentukan Sugiyanto dan Sudjarwo ( 1992: 227 ) menyatakan, "Fleksibilitas adalah unsur kemampuan fisik yang memungkinkan sesuatu bagian tubuh bergerak dengan luas rentang sendi semaksimal mungkin." Menurut Sudjarwo ( 1993 : 33 ) menyatakan kemampuan seseorang untuk melakukan gerakan dengan amplitude gerakan yang luas." Hal senada dikemukakan M. Sajoto ( 1995 : 9) bahwa, "Daya lentur (flexibity) adalah efektivitas seseorang dalam penyesuaian diri untuk segalaaktivitas dengan penguluiran tubuh yang luas.

Pada prinsipnya pengertian kelentukan yang dikemukakan tiga ahli tersebut mempunyai pengertian yang hampir sama, sehingga dapat dirumuskan pengertian kelentukan togok adalah keleluasaan gerak persendian elastisitas otot-otot pada togok dan di sekitarnya untuk melakukan aktivitas atau gerakan secara luas tanpa menimbulkan gangguan pada bagian - bagian tersebut. Dengan demikian orang-orang yang lentuk adalah orang yang mempunyai ruang gerak yang luas dalam sendi-sendinya dan mempunyai otot - otot yang elastis.

\section{KERANGKA PEMIKIRAN}

Nomor loncat katak Kids Athletic merupakan salah satu nomor kids atletics yang digunakan untuk siswa putra Sekolah Dasar. Untuk dapat mempunyai kemampuan yang baik dalam nomor loncat katakKids Athletic perlu ditunjang oleh kondisi fisik sepertipower otot tungkai, kekuatan otot lengan dan kelentukan. Power otot tungkai pada saat melompat, terutama saat melakukan awalan sangat diperlukan untuk mendorong tubuh ke depan yang lebih kuat. Dengan kekuatan eksplosif otot tungkai dalam gerakan loncat katak Kids Athletic pada waktu awalan akan mendapatkan keuntungan dorongan ke depan yang lebih kuat sehingga dengan memiliki power otot tungkai yang baik akan dapat membantu meningkatkan prestasi loncat katak menjadi lebih baik.

Kekuatan otot lengan adalah kemampuan otot atau segerombolan otot di lengan untuk mengatasi suatu beban atau tahanan untuk menjalankan suatu aktifitas.Kekuatan otot lengan adalah komponen kondisi fisik yang dapat 
(jasmani)

mendukung dalam gerakan loncat katak bolavoli. Loncat katak Kids Athletic merupakan gerakan yang melibatkan anggota gerak tubuh bagian atas yaitu lengan. Pada gerakan loncat katakKids Athletic, pemain dituntut memiliki kekuatan otot lengan yang memadai untuk dapat melakukan gerakan meloncat yang kuat.

Dalam gerakan loncat katakKids Athletic sangat sangat dibutuhkan kelentukan terutama kelentukan togok.Kelentukan togok berperan dalam gerakan loncat katakKids Athletic terutama saat melakukan awalan dan pada saat melakukan lompatan. Pada saat kaki dilentingkan dengan dibantu tolakan kedua kaki, maka tubuh akan terangkat seperti busur menuju ke sikap berdiri. Pada gerakan yang demikian keleluasaan gerak persendian dan elastisitas otot - otot sangat berperan didalamnya. Jika pada posisi tubuh melengkung seperti busur didukung kelentukan togok yang baik, gerakan dalam dilakukan dengan lancar, tidak kaku, sehingga akan lebih mudah menuju ke sikap mendarat.

\section{HASIL PENELITIAN DAN PEMBAHASAN}

\section{Hubungan Antara Power Otot Tungkai dengan Lompat katak}

Dari hasil analisis korelasi pada dataPower Otot Tungkai dengan Lompat katak, diperoleh nilai $\mathrm{r}$ sebesar 0,473, dimana nilai tersebut lebih besar dari nilai $r_{\text {tabel }}$ pada taraf signifikansi $5 \%$ yaitu 0,361 . Karena nilai $r_{\text {hitung }}>r_{\text {tabel }}$, maka nilai korelasi signifikan. Hal ini berarti bahwaperubahan variansi Lompat katak dipengaruhi oleh komponen variansi Power Otot Tungkai .

\section{Hubungan Antara Kekuatan Otot Lengan dengan Lompat katak}

Berdasarkan hasil analisis yang telah dilKelentukan kan terhadap data Kekuatan Otot Lengan terhadap Lompat katak , diperoleh nilai r sebesar 0,441, dimana nilai tersebut lebih besar dari nilai $r_{\text {tabel }}$ pada taraf signifikansi $5 \%$ yaitu 0,361. Karenanilai $r_{\text {hitung }}>r_{\text {tabel }}$, maka nilai korelasi signifikan. Hal ini berarti bahwa variansi unsur Kekuatan Otot Lengan berpengaruh terhadap peningkatan variansi Lompat katak.

\section{Hubungan Antara Kelentukan dengan Lompat katak}

Berdasarkan hasil analisis yang telah dilKelentukan kan terhadap data Kelentukan terhadap Lompat katak, diperoleh nilai r sebesar 0.469, dimana nilai 
(jasmani)

tersebut lebih kecil dari nilai $r_{\text {tabel }}$ pada taraf signifikansi $5 \%$ yaitu 0,361 . Karena nilai $r_{\text {hitung }}<r_{\text {tabel}}$, maka nilai korelasi signifikan. Dengan demikian dapat disimpulkan bahwa Kelentukan memiliki hubungan yang signifikan terhadap Lompat katak .

\section{Hubungan Power Otot Tungkai , Kekuatan Otot Lengan dan Kelentukan dengan Lompat katak}

Pada Hipotesis dinyatakan bahwa hubungan antara Power Otot Tungkai, Kekuatan Otot Lengan dan Kelentukan dengan Lompat katak di ketahui $\mathrm{R}_{\mathrm{y}(123)}^{2}=$ 0.407 sedangkan $r_{\text {tabel }}$ pada taraf signifikasi 0,05 dan $n=30$ di dapat $r_{\text {tabel }}=0,361$, dengan hasil tersebut $r_{\text {hitung }}>r_{\text {tabel5 } \%}$ dan $f_{\text {hitung }}=7.5284$, sedangkan $f_{\text {tabel5\% dengan }}$ $\mathrm{db} 3: 26=2,89$, ini berarti $\mathrm{F}_{0}>\mathrm{F}_{\text {tabel5\% }}$ Maka hipotesis di terima.

\section{KESIMPULAN, IMPLIKASI DAN SARAN}

\section{Simpulan}

Berdasarkan hasil penelitian dan hasil analisis regresi dan korelasi product moment yang telah dilKelentukan kan dapat diperoleh simpulan sebagai berikut:

A. Ada hubungan yang signifikanantara Power Otot Tungkai dengan Lompat katak, $r_{\text {hitung }}=0,473>r_{\text {tabel } 5 \%}=0,361$.

B. Ada hubungan yang signifikan antara Kekuatan Otot Lengan dengan Lompat katak, $\mathrm{r}_{\text {hitung }}=0,441>\mathrm{r}_{\text {tabel }} \%=0,361$.

C. Ada hubungan yang signifikan antara Kelentukan dengan Lompat katak , $r_{\text {hitung }}=0.469>r_{\text {tabel } 5 \%}=0,361$.

D. Ada hubungan yang signifikan antara Power Otot Tungkai , Kekuatan Otot Lengan dan Kelentukan dengan Lompat katak , $\mathrm{R}_{\mathrm{y}(123)}^{2}$ sebesar $0.407>\mathrm{r}_{\text {tabel5 }}$ \% pada taraf signifikansi 5\% sebesar 0.361 dan $\mathrm{F}_{0}$ sebesar $7.5284>\mathrm{f}_{\text {tabel }}$ pada taraf signifikansi $5 \%$ sebesar 2,89.

\section{Saran}

Sehubungan dengan simpulan yang telah diambil, maka kepada guru olahraga, khususnya di Sekolahan, disarankan agar:

A. Dalam upaya untuk meningkatkan Lompat katak hendaknya memberikan latihan Power Otot Tungkai , Kekuatan Otot Lengan dan Kelentukan . 
B. Latihan fisik yang diberikan harus proporsional. Besarnya porsi latihan untuk tiap unsur Power Otot Tungkai ,Kekuatan Otot Lengan dan Kelentukan disesuaikan dengan besarnya nilai hubungan tiap variabel terhadap Lompat katak .

\section{DAFTAR PUSTAKA}

Ahmad Sofian. 1979. Macam Otot Dalam Tubuh Manusia. Jakarta: Tragung.

Bompa, T.O. 1980. Theory and Methodology Of Training. London : The CV. Mosby Company.

Dangsina Moeloek dan Arjatmo Tjokronagara. 1984. Kesehatan dan Olahraga. Jakarta: Fakultas Kedokteran Universitas Indonesia.

Foss, L.M. 1998.Physiological Basis Of Exercise and Sport. Mc Graw Hill Book, New York.

IAAF Kids Athletics 2002. A Team Event for Children.Monako : IAAF.

Johnson, B.L. \& Nelson, J.K. 1986.Practical Measurument For Evaluation InPhysical Education. Edina, MN: Burgess.

Mochamad Sajoto. 1995. Pengembangan Dan Pembinaan Kekuatan Kondisi FisikDalam Olahraga. Jakarta: Dahara prize Offset.

PASI.2000. Petunjuk Pelaksanaan Lomba Athletics. Jakarta: PASI

Rusli Lutan, Dkk. 1992. Pengertian Kelentukan.Jakarta : Depdikbud. Dirjendikti.

Singer, R. N. 1980. Motor Learning and Human Performance:An Application toMotor Skills and Movement Behaviors. New York: Macmillan Publishing.

Soedarminto.1991. Otot Yang Terdapat Pada Tungkai.Jakarta : Depdikbud.

Suharno. H. P. 1993..Power Otot Tungkai Dan Kelentukan. Yogyakarta: IKIPYogyakarta.

Suyono.2002. IAAF Kid's Athletics. Jakarta: Staff Set-IAAF RDC Jakarta.

Syaifuddin. 1997. Anatomi Otot Punggung. Jakarta: Kedokteran EGC.

Thompson, P.J.L. 1991. Introduction to Coaching Theory. Monaco: IAAF.

Tisnowati Tamat. 2003. Atletik. Jakarta: Universitas Terbuka. 